\title{
MODEL EVALUASI PENDIDIKAN BERBASIS PROSES MENURUT HADIS
}

\author{
Nurul Zainab \\ Jurusan Tarbiyah Sekolah Tinggi Agama Islam Negeri, Pamekasan Jawa Timur \\ nurulzainab40@gmail.com
}

Diterima 08 Juni 2017 | Direview 12 Juni 2017 | Diterbitkan 01 Oktober 2018

\begin{abstract}
:
Hadith is the second source of knowledge for Muslims after the Qur'an. The proclamation of a hadith needs to be extracted, to provide power for the development of science because it really comes from the words, actions and taqrir of Prophet Muhammad $S A W$. In the context of education, there are many badiths that can serve as the basis of developing the subject of educational evaluation. Based on the study of hadith contained in this article, it is found a hadith history at-Tirmidhi which explains the virtue of honesty and get away from the nature of lies. In addition to the results of research, sanad and matan hadith, this hadith is sabih because the aspect of the content of the hadith does not conflict with the Qur'an and other sabih hadiths. In this article it is also found the meaning of hadith and its implications for the development of educational evaluation that can provide treasures for educators in carrying out the assessment process in learning.
\end{abstract}

Keywords: Assessment process; Evaluation of education; Hadith

\begin{abstract}
Abstrak
Hadis merupakan sumber pengetahuan kedua bagi umat muslim setelah al-Qur'an, kehujjahan sebuah hadis perlu digali sehingga memberikan kekuatan bagi pengembangan ilmu pengetahuan karena memang benar-benar berasal dari ucapan, tindakan maupun taqrir Nabi Muhammad SAW. Dalam konteks pendidikan khususnya evaluasi banyak hadis yang dijadikan sumber landasan pengembangan evaluasi. Berdasarkan penelitian hadis yang ada di dalam artikel ini, didapati sebuah hadis riwayat at-Tirmidzi yang menjelaskan keutamaan kejujuran dan menjaubi sifat kebohongan. Hadits ini bernilai shohih karena secara jalur sanad tidak ada yang terputus dan dari aspek isi badits tidak bertentangan dengan alQur'an dan hadits-hadits shobih lainnya. Selain hasil penelitian sanad dan matan hadits. Di dalam artikel ini juga didapati makna hadis serta implikasinya terhadap pengembangan evaluasi pendidikan yang dapat memberikan khazanah bagi pendidik. dalam melaksanakan proses penilaian dalam pembelajaran.
\end{abstract}

Kata kunci: Proses penilaian; Evaluasi pendidikan; Hadis 


\section{Pendahuluan}

Menurut Suharsimi, Arikunto, valuasi adalah kegiatan untuk mengumpulkan informasi tentang bekerjanya sesuatu, yang selanjutnya informasi tersebut digunakan untuk menentukan alternatif yang tepat dalam mengambil keputusan. Fungsi utama evaluasi dalam hal ini adalah menyediakan informasi-informasi yang berguna bagi pihak decision maker untuk menentukan kebijakan yang akan diambil berdasarkan evaluasi yang telah dilakukan.Evaluasi merupakan sebuah proses yang dilakukan oleh seseorang untuk melihat sejauh mana keberhasilan sebuahprogram.

Pada proses pendidikan dan pembelajaran, evaluasi sangat penting untuk diterapkan sebagai alat ukur keberhasilan program pendidikan. Berbagai model evaluasi dikembangkan oleh para pakar demi tercapai model yang tepat pada setiap proses pendidikan. Beberapa model tersebut adalah Goal oriented evaluation, decision oriented evaluation, transactional evaluation, evaluation research, goal free evaluationdanAdversary Evaluation.Pendidikan agama Islam adalah pendidikan yang berlandaskan Al-Qur'an dan Hadits. Setiap hal yang terkait dengan pendidikan harus mempunyai landasan yang jelas dari Al-Qur'an dan Hadits, dalam hal ini evaluasi pendidikan khususnya model goal free evaluation. Berdasarkan beberapa referensi yang penulis baca, hadits yang biasa digunakan sebagai landasan goal free evaluation adalah hadits tentang keutamaan kejujuran berikut:

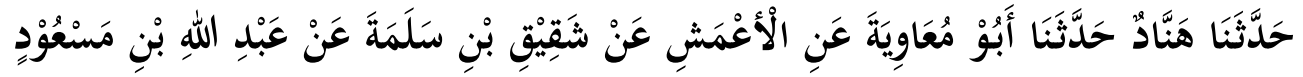

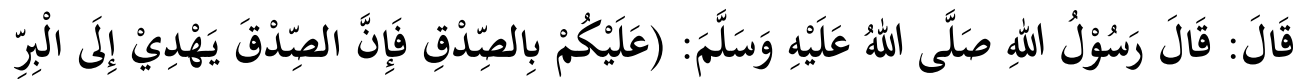

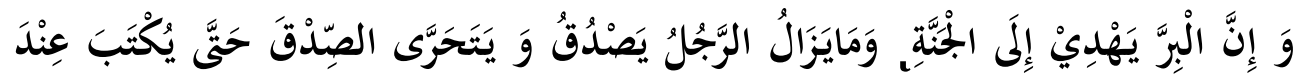

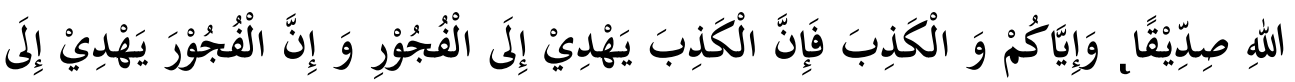

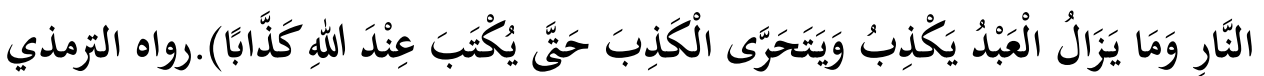
Artinya: "Hannad menceritakan kepada kami, Abu Mu'awiyah menceritakan kepada kami, dari al-A'masy, dari Syaqiq bin Salamah, dari Abdullah bin Mas'ud, ia mengatakan bahwa Rasulullah saw. bersabda: "Pegang teguh kejujuran! Kejujuran itu menunjuk.kan jalan kebaikan dan kebaikan itu mengantarkan ke surga. Seseorang dapat dinilai jujur bila ia (benar-benar) mengimplementasikan nilai kejujuran tersebut. Waspadalah kalian terhadap kebohongan! Sungguh, kebohongan itu menunjukekan jalan kesesatan dan kesesatan itu mengantarkan ke neraka. Karenanya, seseorang yang seringkali 
berbohong serta melakukan tindak kebohongan, bingga ia dicatat di sisi Allah SWT. sebagai pembohong."

\section{Pembahasan}

Kedudukan hadits yang secara struktural menempati urutan kedua sesudah Al-Qur'an sebagai sumber pokok hukum Islam, menyebabkan hadits yang akan kita pedomani haruslah jelas statusnya. Kehati-hatian akan kualitas keshahihan hadits menjadi hal yang mutlak sebelum kita menjadikannya sebagai sumber dan pedoman, apalagi dimaklumi bahwa dari segi periwayatan, hadits pada umumnya bersifat ₹̧hanni al-wurud. ${ }^{1}$ Hadis ang digunakan sebagai bujjah atau landasan seharusnya adalah hadits shahih dan maqbul al-bujjah. Kenyataannya, beberapa mahasiswa bahkan pakar pendidikan memberikan landasan hadits tanpa meneliti apakah hadits tersebut shahih atau tidak. Agar terhindar dari penggunakan hadits yang tidak shahih sebagai landasan evaluasi pendidikan, maka perlu dilakukan penelitian hadits.

\section{KAJIAN SANAD HADITS}

Melihat kualitas hadits, perlu dilakukan dalam istilah penelitian hadits yaitu men-takbrij hadits ${ }^{2}$ yang akan dibahas dengan melacak kata kunci fujurdalam al-Mu'jam al-Mufahras li Alfadz al-Hadits al-Nabany, ${ }^{3}$ hadits yang diriwayatkan at-Tirmidzi sebagai landasan model evaluasi pendidikan

1 Arifuddin Ahmad, Paradigma Baru Memahami Hadits Nabi; Refleksi Pemikiran Pembaruan Prof. Dr. Muhammad Syuhudi Ismail (Cet. I; Jakarta: Renaisan, 2005), 1

${ }^{2}$ Takhrij al-hadits adalah kegiatan penelusuran atau pencarian hadits pada berbagai kitab rujukan sebagai sumber asli dari hadits yang bersangkutan. Dalam kitab sumber tersebut dikemukakan secara lengkap sanad dan matan hadits. Lihat M. Syuhudi Ismail, Metodologi Penelitian Hadits Nabi (Cet. I; Jakarta: Bulan Bintang, 1993), 43. Terkait kegiatan takhrij al-hadits, terdapat metodologi yang bervariasi, yakni; (1) berdasarkan lafaz pertama matan hadits; (2) berdasarkan lafaz dalam matan hadits; (3) berdasarkan tema (al-mawdlu'i); (4) berdasarkan periwayat pertama (al-rawi al-awwal); dan (5) berdasarkan status hadits. Lihat Abu Muhammad Abd al-Hadi bin Abd al-Qadir bin al-Hadi, Turuq Takhrij Hadits Rasulillah (Mesir: Dar al-Fikr, t.th.), 23-26. Lihat pula Mahmud Tahhan, Ushul al-Takhrij wa Dirasat al-Asanid (Beirut: al-Matba'ah al-Arabiyyah, 1978) 9-10, selanjutnya dibandingkan dengan M. Syuhudi Ismail, Metodologi Penelitian Hadits Nabi, 46-49, yang menyatakan bahwa takhrij al-hadits terbagi menjadi dua, yakni bi al alfadz dan bi almawdlu'i.

${ }^{3}$ Wensinck, A.J, al-Mu'jam al-Mufahras li Alfadz al-Hadits al-Nabawi, Leiden: E.J. Brill, 1936 
berbasis proses ini ditemukan dalam berbagai kitab dengan redaksi sebagai berikut:

a. Shahih Muslim Juz 4 No Hadits 2607

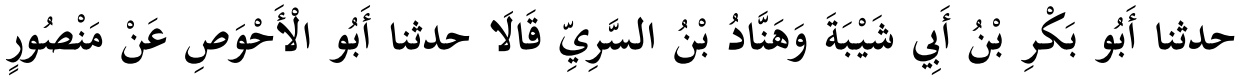

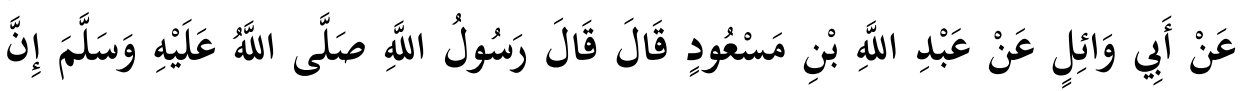

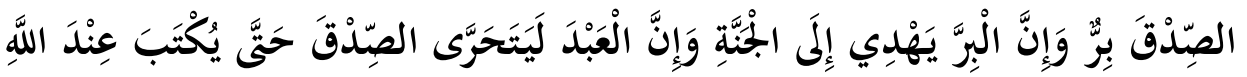

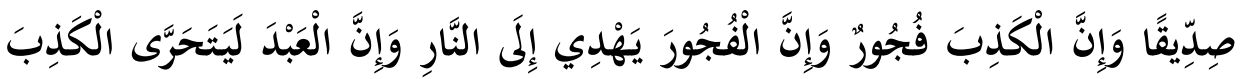

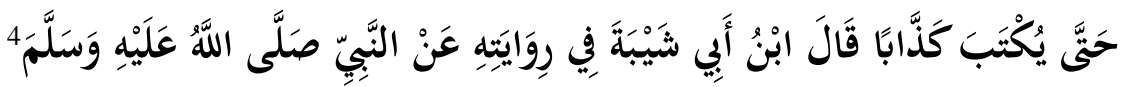

b. Sunan Abi Daud No Hadits 4989

حدثنا أبو بكر بن أبي شيبة ثنا وكيع أخبرنا الأعمش ح وثنا مسدد ثنا عبد الله بن داود ثنا الأعمش عن أبي وائل عن عبد الله قال : قال رسول الله صلى الله عليه و سلم " إياكم والكذب فإن الكذب يهدي إلى الفجور وإن الفجور يهدي إلى النار وإن الرجل ليكذب ويتحرى الكذب حتى يكتب عند الله كذابا وعليكم بالصدق فإن الصدق يهدي إلى البر وإن البر يهدي إلى الجنة وإن الرجل ليصدق ويتحرى الصدق حتى يكتب عند الله صديقا "5.

Hadits yang diriwayatkan at-Tirmidzi sebagai hadits evaluasi pendidikan tersebut memiliki jalur sanad sebagai berikut: Abu Isa AlTirmidzi, Hannad Ibn Siri, Abu Mu'awiyah, Al-A'masy, Syaqiq Ibn Salamah dan Abdullah Ibn Mas'ud. ${ }^{6}$ Adapun biografi masing-masing

\footnotetext{
${ }^{4}$ Muslim ibn al-Hujjaj Abu al-Husain al-Qusyairi al-Naisaburi, Shahih Muslim Juz 4, (Beirut: Dar Ihya al-Turats al-'Araby, t.t), 2012. Lihat juga al-Maktabah al-Syamilah: Shahih Muslim

${ }^{5}$ Sulaiman ibn al-Asy'ats Abu Daud al-Sijistani al-Azdi, Sunan Abi Daud, (Beirut: Dar alFikr, t.t.). Lihat juga Al-Maktabah Al-Syamilah: Sunan Abi Daud

${ }^{6}$ Abi 'Isa Muhammad ibn 'Isa ibn Saurah Al-Tirmidzi, Sunan Al-Tirmidzi, Juz 3, (Beirut Lebanon: Dar El-Fikr, 2003/ 1424 H), 391
} 
perawi, analisis kebersambungan sanad, kualitas pribadi dan kapasitas intelektual perawi, serta terbebasnya sanad tersebut dari syadz dan 'illat, dapat dilihat dalam tabel berikut ini.

Tabel 1

Biografi Sanad Hadist at-Tirmidzi

\begin{tabular}{|c|c|c|c|c|}
\hline $\begin{array}{l}\text { Nama } \\
\text { Perawi }\end{array}$ & $\begin{array}{l}\text { TL-TW/ } \\
\text { Umur }\end{array}$ & Guru & Murid & Jarh wa Ta'dil \\
\hline $\begin{array}{l}\text { Muhammad } \\
\text { ibn Isa ibn } \\
\text { Saurah Ibn } \\
\text { Musa ibn } \\
\text { Al-Dhahaky } \\
\text { (Abu Isa Al- }^{\text {Tirmidzi) }}{ }^{7}\end{array}$ & $\begin{array}{l}\text { L: } 209 \mathrm{H} \\
\text { W: } 279 \mathrm{H} \\
\text { U: } 70 \text { th. }\end{array}$ & $\begin{array}{l}35 \text { orang } \\
\text { - Qutaibah } \\
\text { ibn Said } \\
\text { - Nasr ibn } \\
\text { Ali } \\
-\underline{\text { Hannad }} \\
\underline{\underline{\text { ibn Al- }}} \\
\underline{\text { Siri }}\end{array}$ & $\begin{array}{l}26 \text { orang } \\
- \text { Ahmad } \\
\text { ibn Yusuf } \\
\text { Al-Nasafi } \\
\text { - Al-Husain } \\
\text { ibn Yusuf } \\
\text { Al-Farabri } \\
\text { - Haitsam } \\
\text { ibn Qulaib } \\
\text { al-Syasyi }\end{array}$ & $\begin{array}{l}\text { - Ibn Hibban } \\
\text { memasukkan } \\
\text { nya dalam } \\
\text { kitab al-Tsiqat } \\
\text { dan } \\
\text { mengatakan } \\
\text { bahwa beliau } \\
\text { termasuk ke } \\
\text { dalam orang- } \\
\text { orang yang } \\
\text { mengumpulk } \\
\text { an, menulis } \\
\text { dan } \\
\text { menghafal } \\
\text { hadits; } \\
\text { - Al-Dzahabi } \\
\text { dalam “Al- } \\
\text { Mizan”: } \\
\text { Tsiqah } \\
\text { Mujamma' } \\
\text { 'alaihi; } \\
\text { - Al-Khalili: } \\
\text { Tsiqah } \\
\text { Muttafaqun } \\
\text { 'alaihi; }\end{array}$ \\
\hline
\end{tabular}

7Jamal al-Din Abi al-Hujjaj Yusuf al-Mazzi, Tahdzib al-Kamal fi Asma' al-Rijal, Jilid 26, (Baghdad: Muassasah al-Risalah, 1983), 250

${ }^{8} \mathrm{CD}$ Maktabah al-A'lām wa Al-Tarājim

${ }^{9} \mathrm{Al}-\mathrm{Mazzi}$, Tahdzib al-Kamal, 250-251 


\begin{tabular}{|c|c|c|c|c|}
\hline & & & & $\begin{array}{l}\text { - Ibn Hajar } \\
\text { dalam al- } \\
\text { Taqrib: } \\
\text { Tsiqah } \\
\text { Hafidz. }\end{array}$ \\
\hline $\begin{array}{l}\text { Hannad ibn } \\
\text { Al-Siri (Abu } \\
\text { Al-Siri al- } \\
\text { Kufiy) }\end{array}$ & $\begin{array}{l}\mathrm{L}: 152 \mathrm{H} \\
\mathrm{W}: 243 \mathrm{H} \\
\mathrm{U:} 91 \mathrm{th}^{12}\end{array}$ & $\begin{array}{l}39 \text { orang } \\
\text { - Waki' ibn } \\
\text { Al-Jarrah } \\
\text { - Yahya } \\
\text { ibn Ma'in } \\
\text { - } \underline{\text { Abu }} \\
\underline{\text { Mu'awiy }} \\
\underline{\text { ah Al- }} \\
\underline{\text { Dhariri }}{ }^{13}\end{array}$ & $\begin{array}{l}12 \text { orang } \\
\text { - Al-Bukhari } \\
\text { - Jamaah } \\
\text { - Ahmad } \\
\text { ibn } \\
\text { Mansur } \\
\text { Al- } \\
\text { Ramadi }^{14}\end{array}$ & $\begin{array}{l}\text { - Ahmad ibn } \\
\text { Hanbal: } \\
\text { "Alaikum bi } \\
\text { Hannad; } \\
\text { - Abu Hatim: } \\
\text { Shaduq } \\
\text { - Qutaibah ibn } \\
\text { Sa'id: Saya } \\
\text { tidak pernah } \\
\text { melihat Waki' } \\
\text { mengagungka } \\
\text { n seseorang } \\
\text { lebih dari } \\
\text { Hannad; } \\
\text { - Al-Nasai: } \\
\text { Tsiqah; } \\
\text { - Ibn Hibban } \\
\text { memasukkan } \\
\text { nya dalam } \\
\text { kitab al- } \\
\text { Tsiqat; } \\
\text { - Ibn Hajar } \\
\text { dalam Taqrib } \\
\text { al-Tahdzib: } \\
\text { Tsiqah. }\end{array}$ \\
\hline
\end{tabular}

${ }^{10} \mathrm{Al}$ - Mazzi, Tahdzib al-Kamal fi Asma' al-Rijal, Jilid 26, 252

${ }^{11}$ Al-Mazzi, Tahdzib al-Kamal, 305

${ }^{12}$ Jamal al-Din Abi al-Hujjaj Yusuf al-Mazzi, Tahdzib al-Kamal fi Asma' al-Rijal, Juz 19,

(Beirut Lebanon: Dar al-Fikr, 1994), 306

${ }^{13}$ Al-Mazzi,Tahdzib al-Kamal, juz 19, 306

${ }^{14} \mathrm{CD}$ Maktabah al-A'lām wa Al-Tarājim

${ }^{15} \mathrm{Al}-\mathrm{Mazzi}$,Tahdzib al-Kamal, juz 19, 306 


\begin{tabular}{|c|c|c|c|c|}
\hline $\begin{array}{l}\text { Abu } \\
\text { Mu'awiyah } \\
\text { Muhammad } \\
\text { ibn Khazim } \\
\text { Al-Dhariri1 }\end{array}$ & $\begin{array}{l}\text { L: } 113 \mathrm{H} \\
\mathrm{W}: 194 / \\
195 \mathrm{H} \\
\mathrm{U}: 82 \mathrm{th}^{17}\end{array}$ & 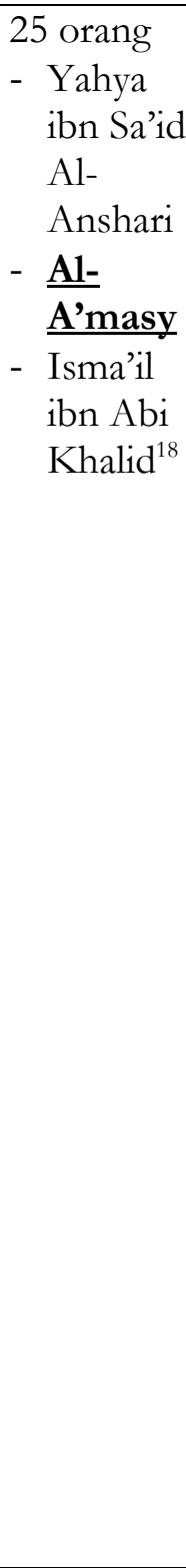 & $\begin{array}{l}40 \text { orang: } \\
\text { - } \text { Hannad } \\
\text { - Qutaibah } \\
\text { - 'Ali ibn } \\
\text { Harb' }^{19}\end{array}$ & $\begin{array}{l}\text { - Al-A'masy } \\
\text { mengedepank } \\
\text { an Abu } \\
\text { Mu'awiyah } \\
\text { - Abdullah ibn } \\
\text { Ahmad dari } \\
\text { ayahnya: Abu } \\
\text { Mu'awiyah } \\
\text { tidak } \\
\text { menghafal } \\
\text { hadits dengan } \\
\text { baik selain } \\
\text { hadits dari al- } \\
\text { A'masy, dan } \\
\text { berkata } \\
\text { Wallahi dia } \\
\text { penghafal Al- } \\
\text { Qur'an } \\
\text { - Yahya ibn } \\
\text { Mu'in: Dia } \\
\text { adalah } \\
\text { sahabat al- } \\
\text { A'masy yang } \\
\text { paling } \\
\text { tsabtsetelah } \\
\text { sufyan dan } \\
\text { Syu'bah } \\
\text { Al-'Ijli: } \\
\text { Tsiqah, } \\
\text { Layyin al- } \\
\text { Qaul fihi } \\
\text { - Ya'qub ibn } \\
\text { Syaibah: }\end{array}$ \\
\hline
\end{tabular}

${ }^{16}$ Al-Mazzi,Tahdzib al-Kamal, juz 22, 46

${ }^{17} \mathrm{CD}$ Maktabah al-A'lām wa Al-Tarājim

${ }^{18} \mathrm{CD}$ Maktabah al-A' lām wa Al-Tarājim

${ }^{19} \mathrm{CD}$ Maktabah al-A'lām wa Al-Tarājim 


\begin{tabular}{|c|c|c|c|c|}
\hline & & & & $\begin{array}{l}\text { Tsiqah } \\
\text { - Abu Daud: } \\
\text { dia adalah rais } \\
\text { al marïnah di } \\
\text { Kufah } \\
\text { - Nasai: Tsiqah } \\
\text { - } \text { Ibn Khowasy: } \\
\text { Shaduq, dia } \\
\text { tsiqah dalam } \\
\text { meriwayatkan } \\
\text { hadits dari al- } \\
\text { A'masy tapi } \\
\text { selain al } \\
\text { - A'masy dia } \\
\text { bermasalah } \\
\text { - Ibn Hibban: } \\
\text { Hafidhan } \\
\text { Muttaqan } \\
\text { - Jarir ibn Abd } \\
\text { al-Hamid: } \\
\text { Tidak ada } \\
\text { yang lebih } \\
\text { hafal hadits } \\
\text { al-A'masy } \\
\text { daripada Abu } \\
\text { Mu'awiyah }{ }^{20} \\
\end{array}$ \\
\hline $\begin{array}{l}\text { Sulaiman } \\
\text { ibn Mihran } \\
\text { Al-Asadi Al- } \\
\text { Kahili (Al- } \\
\text { A'masy) }\end{array}$ & $\begin{array}{l}\text { L: } 59 \mathrm{H} \\
\text { W: } 147 / \\
148 \mathrm{H} \\
\mathrm{U}: 88 \mathrm{th}^{22}\end{array}$ & $\begin{array}{l}102 \text { orang } \\
\text { - Sa'id ibn } \\
\text { Jubair } \\
\text { - } \underline{\text { Abi Wail }} \\
\underline{\text { Syaqiq }} \\
\underline{\underline{\text { ibn }}} \\
\underline{\text { Salamah }}\end{array}$ & $\begin{array}{l}105 \text { orang } \\
\text { - Abu } \\
\text { Khalid Al- } \\
\text { Ahmar } \\
\text { - Waki' ibn } \\
\text { Jarrah } \\
\text { - } \underline{\text { Abu }}\end{array}$ & $\begin{array}{l}\text { - Ali ibn Al- } \\
\text { Madini: Al- } \\
\text { A'masy } \\
\text { adalah salah } \\
\text { satu dari } 6 \\
\text { orang } \\
\text { pengembang }\end{array}$ \\
\hline
\end{tabular}

${ }^{20} \mathrm{CD}$ Maktabah al-A'lām wa Al-Tarājim

${ }^{21}$ Al-Mazzi,Tahdzib al-Kamal, juz 8, 106

${ }^{22}$ Al-Mazzi,Tahdzib al-Kamal, juz 8, 114 


\begin{tabular}{|c|c|c|c|c|}
\hline & & $\begin{array}{l}\text { al-Asadi } \\
\text { - Thariq } \\
\text { ibn Abd } \\
\text { Al- } \\
\text { Rahman }\end{array}$ & $\begin{array}{l}\text { Mu'awiya } \\
\underline{\text { h Al- }} \\
\underline{\text { Dhariri }}\end{array}$ & $\begin{array}{l}\text { dan penjaga } \\
\text { ilmu } \\
\text { - 'Ashim Al- } \\
\text { Ahwal: } \\
\text { A'lama al-nas } \\
\text { - Zuhair ibn } \\
\text { Mu'awiyah: } \\
\text { “Aku tidak } \\
\text { menemukan } \\
\text { orang yang } \\
\text { lebih cerdas } \\
\text { akalnya } \\
\text { kecuali al- } \\
\text { A'masy dan } \\
\text { Mughirah } \\
\text { - 'Amr ibn 'Ali: } \\
\text { Al-A'masy } \\
\text { dijuluki al- } \\
\text { Mushhaf } \\
\text { karena } \\
\text { kejujurannya } \\
\text { - Ahmad ibn } \\
\text { Abdullah al- } \\
\text { 'Tjli: Tsiqah } \\
\text { Tsabt } \\
\text { - Ishaq ibn } \\
\text { Mansur: } \\
\text { Tsiqah } \\
\text { - Al-Nasai: } \\
\text { Tsiqah } \\
\text { Tsabt. }{ }^{23} \\
\text { Alabali }\end{array}$ \\
\hline $\begin{array}{l}\text { Syaqiq ibn } \\
\text { Salamah }\end{array}$ & $\begin{array}{l}\text { L: } 1 \mathrm{H} \\
\mathrm{W}: 82 \mathrm{H}\end{array}$ & $\begin{array}{l}47 \text { orang } \\
\text { - } \text { Abdulla }\end{array}$ & $\begin{array}{l}37 \text { orang } \\
-\quad \text { Salamah }\end{array}$ & $\begin{array}{l}\text { - 'Ashim ibn } \\
\text { Bahdalah: }\end{array}$ \\
\hline
\end{tabular}

${ }^{23} \mathrm{Al}$-Mazzi,Tahdzib al-Kamal, juz 8, 111-114 


\begin{tabular}{|c|c|c|c|c|}
\hline $\begin{array}{l}\text { (Abu Wail } \\
\text { Al-Asadi) }^{24}\end{array}$ & $\mathrm{U}: 81 \mathrm{th}^{25}$ & $\begin{array}{l}\frac{\text { h ibn }}{\text { Mas'ud }} \\
\text { - Abi } \\
\text { Hurairah } \\
\text { - Aisyah } \\
\text { Ummu } \\
\text { Al- } \\
\text { Mukmini } \\
\mathrm{n}^{26}\end{array}$ & $\begin{array}{l}\text { ibn Kuhail } \\
-\underline{\text { Sulaiman }} \\
\underline{\underline{\text { Al- }}} \\
\underline{\underline{\mathbf{A}^{\prime} \mathrm{masy}}} \\
\text { - 'Amir ibn } \\
\text { Syaqiq' }^{27}\end{array}$ & $\begin{array}{l}\text { Saya tidak } \\
\text { pernah } \\
\text { mendengar } \\
\text { Abu Wail } \\
\text { menghina } \\
\text { seseorang } \\
\text { sama sekali } \\
\text { bahkan } \\
\text { hewan } \\
\text { sekalipun. } \\
\text { - Waki': Tsiqah } \\
\text { - Ishaq ibn } \\
\text { Mansur dari } \\
\text { Yahya ibn } \\
\text { Ma'in: Tsiqah } \\
\text { tidak ada yang } \\
\text { sepertinya } \\
\text { - Muhammad } \\
\text { ibn Sa'ad: } \\
\text { Tsiqah, } \\
\text { meriwayatkan } \\
\text { banyak hadits } \\
\text { - Ibn Hibban } \\
\text { memasukkan } \\
\text { nya dalam } \\
\text { kitab al-Tsiqat } \\
\text { - Ibn Abd Al- } \\
\text { Bir: Tsigah }{ }^{28}\end{array}$ \\
\hline $\begin{array}{l}\text { Abdullah } \\
\text { ibn Mas’ud } \\
\text { ibn Ghafil } \\
\text { ibn Habib }\end{array}$ & $\begin{array}{l}\text { L: } \\
\text { W: } 32 / \\
33 \mathrm{H} \\
\mathrm{U}: 63 \text { th }\end{array}$ & $\begin{array}{l}4 \text { orang } \\
\text { - Nabi } \\
\text { SAW } \\
\text { - Sa'ad ibn }\end{array}$ & $\begin{array}{l}119 \text { orang } \\
-\underline{\text { Abu Wail }} \\
\underline{\text { Syaqiq }} \\
\underline{\text { ibn }}\end{array}$ & $\begin{array}{l}\text { - Said ibn } \\
\text { Mansur: } \\
\text { Isnaduhu } \\
\text { Shahih }\end{array}$ \\
\hline
\end{tabular}

${ }^{24} \mathrm{Al}-\mathrm{Mazzi}, T a h d z i b$ al-Kamal, juz 8, 387

${ }^{25}$ Al-Mazzi,Tahdzib al-Kamal, juz 8, 389-390

${ }^{26} \mathrm{Al}-\mathrm{Mazzi}$ Tahdzib al-Kamal, juz 8, 387

${ }^{27}$ Al-Mazzi,Tahdzib al-Kamal, juz 8, 387-388

${ }^{28}$ Al-Mazzi,Tahdzib al-Kamal, juz 8, 389 


\begin{tabular}{|c|c|c|}
\hline $\begin{array}{l}\text { ibn Syamkhi } \\
\text { ibn } \\
\text { Makhzum }^{29}\end{array}$ & $\begin{array}{l}\text { Mu'adz } \\
\text { al- } \\
\text { Anshari } \\
\text { - Shafwan } \\
\text { ibn 'Assal } \\
\text { al- } \\
\text { Maraddi } \\
\text { - Umar ibn } \\
\text { al- } \\
\text { Khattab }\end{array}$ & $\begin{array}{l}\text { Salamah } \\
\text { - } \text { al-Asady } \\
\text { Abu } \\
\text { Umamah } \\
\text { Shudai ibn } \\
\text { 'Ajlan Al- } \\
\text { Bahili } \\
\text { - 'Amir ibn } \\
\text { Syarahil al- } \\
\text { Sva'bi'31 }\end{array}$ \\
\hline
\end{tabular}

\section{Penilaian Syadz dan Illat pada Sanad Hadis}

Kemungkinan adanya syadr dan illat pada sanad hadits, dapat dilihat dari kebersambungan sanad dan kualitas serta tingkat ketsiqahan perawi. Menurut al-Syafi'i kemungkinan terdapatnya syadspada sanad hadits adalah pada hadits yang diriwayatkan oleh seorang perawi tsiqah bertentangan dengan hadits yang diriwayatkan oleh sejumlah perawi yang juga bersifat tsiqah.

Sedangkan menurut Syuhudi Ismail bentuk illat pada sanad hadits yaitu; pertama, sanad yang tampak bersambung (muttashil) dan sampai kepada Nabi (marfu') ternyata bersambung tetapi hanya sampai kepada sahabat (manquf); kedua, sanad yang tampak muttashil dan marfu' ternyata muttashil tetapi hanya riwayat sahabat dari sahabat lain (mursal); ketiga, terjadi percampuran dengan hadits lain; keempat, kemungkinan terjadi kesalahan penyebutan perawi yang memiliki kesamaan nama, pada kualitas pribadi dan kapasitas intelektualnya (tsiqab) tidak sama ${ }^{32}$

Berdasarkan pendapat di atas, karena sanad dari jalur sanad ini tidak ada pertentangan, sanadnya bersambung dan seluruh perawinya berpredikattsiqah, penulis berkesimpulan bahwa sanad hadits tersebut terbebas dari unsur syadz dan 'illat.

\footnotetext{
${ }^{29} \mathrm{Al}-\mathrm{Mazzi}$ Tahdzib al-Kamal, juz 10, 532

${ }^{30} \mathrm{Al}-\mathrm{Mazzi}$, Tahdzib al-Kamal, jilid 16, 123

${ }^{31}$ Al-Mazzi,Tahdzib al-Kamal, juz 16, 123-124

${ }^{32}$ M. Syuhudi Ismail, Kaidah Keshahihan Sanad Hadits, (Jakarta: Bulan Bintang, 1988), 132
} 


\section{Penilaian Kualitas Sanad Hadis}

Seluruh perawi yang terlibat dalam transmisi hadits tersebut berkualitas tsiqah, kendati salah satu perawi dinilai jarh yaitu Abu Mu'awiyah, akan tetapi penilaian jarb terhadap Abu Mu'awiyah hanya pada hadits yang dia riwayatkan dari selain al-A'masy. Karena hadits ini adalah hadits yang diriwayatkan Abu Mu'awiyah dari al-A'masy, maka ia berkualitas tsiqah. Meskipun hanya satu perawi yang sampai pada peringkat tertinggi, namun secara umum peringkat mereka hanya sampai pada peringkat ke tiga.

Melihat lambang periwayatan hadits yang mengantarai antara transmiter pertama hingga ke tiga yang menggunakan lafadz 'an, maka hadits tersebut termasuk ke dalam hadits mu'an'an. Namun demikian, berpegang pada kebersambungan sanad dan kualitas perawi yang berpredikat tsiqah, secara otomatis dapat menepis kecurigaan adanya tadlis, sehingga sanad hadits tersebut tergolong muttashil marfu'.

Dengan memperhatikan kaedah keshahihan hadits, seluruh kriterianya telah terpenuhi oleh sanad tersebut kecuali ke-tsiqah-an perawi yang tidak sampai pada peringkat ta'dil tertinggi. Oleh karena itu, penulis memandang bahwa sanad hadits tersebut berpredikat shabih. Dengan demikian, hadits tersebu maqbul al-hujjah dan hadits redaksi yang semakna juga di-takhrij oleh Muslim dalam kitab Shabibnya dan Abu Daud dalam kitab Sunannya.

\section{KAJIAN MATAN HADITS}

Penelitian terhadap kualitas matan hadits diterapkan terhadap hadits yang sanadnya dipastikan berkualitas maqbul al-hujjah (shahib atau hasan alisnad). Menyimak tolak ukur kritik matan yakni tidak bertentangan dengan ayat al-Qur'an yang sesuai, tidak bertentangan dengan hadits lain yang lebih shahih, tidak bertentangan dengan fakta sejarah, perkembangan ilmu pengetahuan dan rasio.Maka, ditilik dari redaksi dan maknanya, hadits tersebut mengindikasikan sebagai kalam kenabian, hal ini karena kata kuncinya al-bir sejalan dengan al-Qur'an. Di antaranya ada di dalam surat alMuthoffifin dan surat al-Infithor adalah:

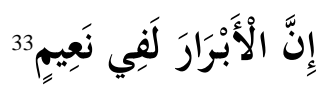

Sesunggubnya orang-orang yang banyak berbakti benar-benar berada dalam surga yang penub kenikmatan.

\footnotetext{
${ }^{33}$ Q.S Al-Muthoffifin ayat 22, lihat juga QS al-Infithor ayat 13
} 
Dasar pijakan dari shiddiq adalah keimanan yang kokoh kepada Allah SWT. Karena hanya iman yang kokohlah yang dapat menjadikan seseorang memiliki integritas tinggi, kejujuran dan amanah (shiddiq). Karena shiddiq merupakan gabungan antara mengharap keridhaan Allah, selalu merasa akan pengawasan Allah, dan istiqamah terhadap nilai kebenaran. Allah SWT berfirman:

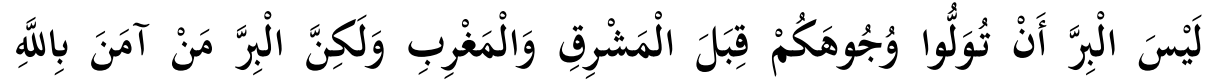

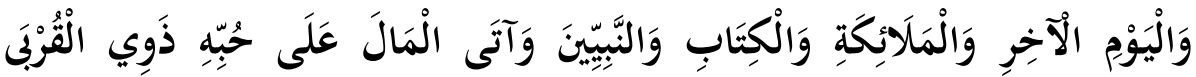
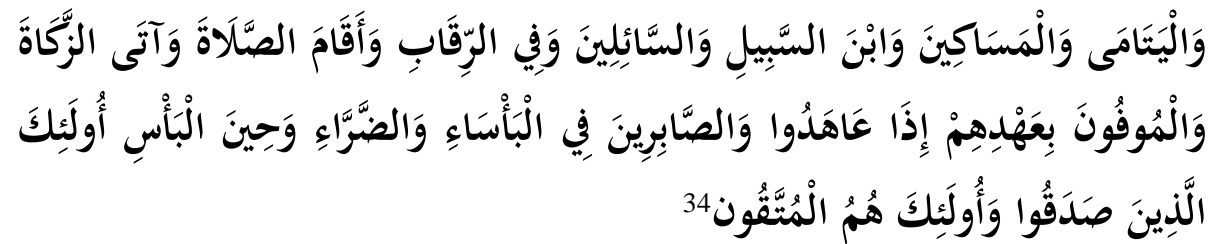

Artinya: Bukanlah menghadapkan wajahmu ke arah timur dan barat itu suatu kebajikan, akan tetapi Sesunggubnya kebajikan itu ialah beriman kepada Allah, hari Kemudian, malaikat-malaikat, kitab-kitab, nabi-nabi dan memberikan harta yang dicintainya kepada kerabatnya, anak-anak yatim, orang-orang miskin, musafir (yang memerlukan pertolongan) dan orang-orang yang meminta-minta; dan (memerdekakan) hamba sabaya, mendirikan shalat, dan menunaikan zakat; dan orang-orang yang menepati janjinya apabila ia berjanji, dan orang-orang yang sabar dalam kesempitan, penderitaan dan dalam peperangan. mereka Itulab orang-orang yang benar (imannya); dan mereka Itulah orang-orang yang bertakwa.

Ayat di atas menggambarkan dimensi yang dicakup oleh shidiq yaitu meliputi keimanan, menginfakkan harta yang dicintai, mendirikan shalat, menunaikan zakat, menepati janji, bersabar dalam kesulitan dan sebagainya. Berdasarkan keterangan tersebut, penulis menyimpulkan bahwa hadits yang penulis teliti tidak bertentangan dengan ayat al-Qur'an. Selain itu, hadits tersebut juga tidak bertentangan dengan hadits yang lebih shahih, yaitu:

$$
\begin{aligned}
& \text { حدثني أبو الطاهر وحرملة بن ييى ( واللفظ لحرملة ) ( قال أبو الطاهر أخبرنا } \\
& \text { وقال حرملة حدثنا عبدالله بن وهب ) حدثني أبو شريح أن سهل بن أبي أمامة بن }
\end{aligned}
$$

${ }^{34}$ Q.S al-Baqoroh ayat 177 


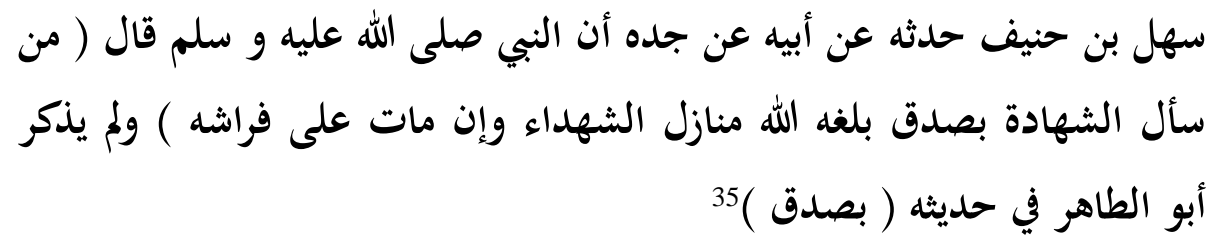

Artinya: "Barang siapa yang meminta kesyahidan kepada Allab SWT dengan sidiq (sebenar-benarnya), maka Allah akan menempatkannya pada posisi syuhada', meskipun ia meninggal di atas ranjangnya."

Fakta sejarah mengungkapkan, bahwa kejujuran selalu membawa kepada kebaikan. Sirah Nabawiyah menggambarkan kepada kita, mengenai keutamaan jujur, diantaranya adalah ketika terjadi peristiwa turunnya surat Al-Lahab. Ketika Rasulullah SAWmemanggil-manggil hampir semua kabilah yang ada untuk meyampaikan sebuah "pesan" yang penting. Dan ternyata semua orang datang berbondong-bondong ke bukit Shofa untuk menyimak apa yang akan beliau sampaikan. Bahkan kalaupun ada orang yang tidak bisa datang, mereka mengutus utusan atau wakil untuk mendengarkan Rasulullah SAW kemudian menyampaikannya kembali kepada orang yang mengutusnya tersebut. Kalaulah sekiranya, Rasulullah SAW tidak memiliki integritas yang tinggi, pastilah seluruh kaum dan seluruh orang tidak akan ada yang mau datang, apalagi hanya sekedar untuk mendengarkan "perkataan" Rasulullah SAW saja.Berdasarkan kesesuaian matan hadits tersebut dengan tolok ukur keshahihannya (redaksi dan matannya sejalan dengan Al-Qur'an, hadits yang lebih shahih, fakta sejarah dan ilmu pengetahuan), penulis berkesimpulan bahwa matan hadits tersebut maqbul untuk dijadikan bujjah.

\section{MAKNA HADIS DAN IMPLIKASINYA TERHADAP MODEL EVALUASI PENDIDIKAN BERBASIS PROSES}

Hadits ini menggambarkan tentang adanya dua hakekat perbedaan yang begitu jauh, sejauh perbedaan antara surga dan neraka. Hakekat pertama adalah mengenai al-shidq (kejujuran \& kebenaran iman), yang digambarkan Rasulullah SAW sebagai pintu gerbang kebaikan yang akan mengantarkan seseorang ke surga. Sementara hakekat yang kedua adalah

\footnotetext{
${ }^{35}$ Shahih Muslim, al-Maktabah al-Syamilah
} 
kedustaan (al-kad₹b), yang merupakan pintu gerbang keburukan yang akan mengantarkan pelakunya ke dalam neraka.

Rasulullah SAW ketika menggambarkan kedua hal di atas, sekaligus mengaitkan juga dengan mashirah (kesudahan) dua sifat yang berbeda tadi, yaitu surga bagi yang shadiq serta neraka bagi yang kadzib. Faedahnya adalah untuk memberikan tadzkir yang mendalam, serta tidak menjadikan dua hal tersebut sebagai masalah yang ringan. Karena secara tabi'at, manusia seringkali menganggap remeh keduanya. Sementara kesudahan dari kedua sifat di atas sangat jauh berbeda, sejauh perbedaan antara surga dan neraka.

Pada kedua sifat yang digambarkan Rasulullah SAW di atas, selalu diikuti dengan perilaku manusia terhadap kedua sifat tersebut, hingga manusia akan menjadi salah satu diantara keduanya; shadiq atau kadrib. Artinya, untuk dikatakan bahwa seseorang itu adalah shadiq misalnya, ia harus membuktikannya dengan perbuatannya sendiri, hingga ia dengan sendirinya akan mendapatkan "gelar" sifat tersebut. Sebaliknya, seseorang yang dikatakan sebagai pendusta, adalah hasil dari perilaku dan perbuatannya, yang akhirnya menjadikannya sebagai pendusta.

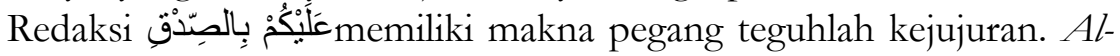
Shidqudalam arti sempit adalah sesuainya ucapan lisan dengan kenyataan. ${ }^{36}$ Dan dalam pengertian yang lebih umum adalah sesuainya lahir dan batin. Maka orang yang jujur bersama Allah SW'T. dan bersama manusia adalah yang sesuai lahir dan batinnya. Karena itulah, orang munafik disebut sebagai kebalikan orang yang jujur, sebagaimana firman Allah SWT dalam AlQuran:

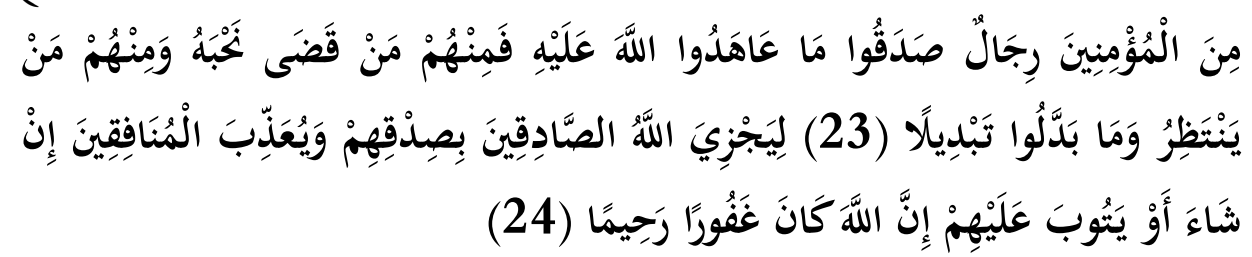

Artinya: 23. di antara orang-orang mukmin itu ada orang-orang yang menepati apa yang telah mereka janjikan kepada Allah; Maka di antara mereka ada yang gugur. dan di antara mereka ada (pula) yang menunggu-nunggu dan mereka tidak merubah (janjinya), 24. supaya Allah memberikan Balasan kepada orang-orang yang benar itu karena kebenarannya, dan menyiksa orang munafik. jika dikehendaki-Nya, atau

\footnotetext{
${ }^{36}$ Muhammad Abdurrahman al-Mubarakfuri, Tuhfatul Ahwadi, (Lebanon: Dar al-Kotob AlIlmiyah, 2005), 76
} 
menerima taubat mereka. Sesunggubnya Allah adalah Maha Pengampun lagi Maha Penyayang. ${ }^{37}$

Jujur termasuk akhlak utama yang terbagi menjadi beberapa bagian. Kejujuran dalam hal ini, meliputi enam hal. Pertama, kejujuran lisan, lawan dari kebohongan; kedua, kejujuran niat, yakni ikhlas dalam berbuat; ketiga, kejujuran dalam bertekad, yakni apapun yang dapat menguatkan tekadnya; keempat, kejujuran dalam merealisasikan tekad yang bulat; kelima, kejujuran dalam berbuat, minimal ada kesamaan antara apa yang diucapkan dengan yang diperbuat; keenam, kejujuran spiritual, seperti jujur dalam mengaplikasikan konsep khawf (rasa takut) dan raja' (rasa harap). ${ }^{38}$

يـاي berarti menunjukkan. Dalam disiplin ilmu nahwu, kata merupakan fi'il mudlari' bina naqis yai, yaitu kata kerja yang dilakukan sekarang atau akan datang. Kata turunan (bentuk derivatifnya) adalah kata الهدايةyang berarti sarana atau petunjuk praktis yang mengantarkan kepada tujuan. Sedangkan kata البرالyang makna asalnya adalah menyebarkan laku kebaikan, namun dalam matan ini memiliki arti perbuatan didasarkan pada keikhlasan dan dilakukan secara kontinu. ${ }^{39}$

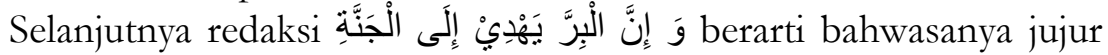
menunjukkan kepada kebaikan yang mana kebaikan tersebut akan membawa seseorang ke jalan masuk surga. Hal ini sesuai dengan firman Allah berikut:

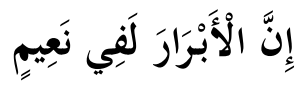

Sesunggubnya orang-orang yang banyak berbakti benar-benar berada dalam surga yang penub kenikmatan ${ }^{40}$

Redaksi وَمَا يَزَ الُُ الرَّجُجلُ يَصْدُقُقُ berarti seseorang yang senantiasa jujur

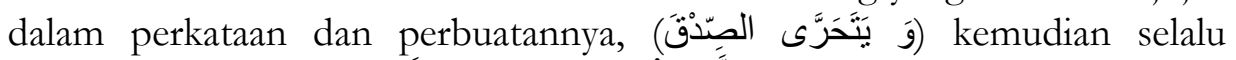

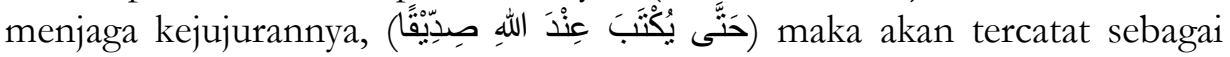

${ }^{37}$ Q.S Al-Ahzab 23-24

${ }^{38} \mathrm{Abu}$ al-Abbas Syihabuddin Ahmad al-Qasthalani,yang selanjutnya disebut alQasthalanni, Irsyad al-Sari li Syarh Shahih al-Bukhari, Volume XIII (Cet. I; Beirut, Dar al-Fikr, 1410 H/1990 M), 127.

${ }^{39}$ Muhammad Abdurrahman al-Mubarakfuri, Tuhfatul Ahwadi, 46

${ }^{40}$ Departemen Agama RI, Al-qur'an dan Terjemahnya, (Bandung, CV. Diponegoro, 2005), 469 
orang yang jujur di sisi Allah. ${ }^{41}$ Orang yang jujur adalah orang yang selalu dan berulang-ulang berbuat jujur sehingga dia dikenal sebagai orang yang jujur.

Kata الفجور berarti keburukan yang merupakan lawan kata البر (kebaikan). Sedangkan redaksi حتى يكتب عند الله كذابا memiliki makna sehingga orang tersebut (yang berbohong) secara terus menerus dijustifikasi sebagai pembohong dan kebohongan itu disebarkan ke seluruh penghuni bumi. Menurut al-Hafidz yang dimaksud dengan يكتب عند الله كذابا adalah menampakkannya kepada seluruh makhluk. ${ }^{42}$

Tidak terdapat penjelasan secara eksplisit di dalam buku syarb hadits, tentang kaitan hadits tersebut dengan evaluasi pendidikan. Namun menurut telaah dan analisis penulis, makna hadits tersebut dapat berimplikasi kepada model-model evaluasi khususnya model evaluasi yang dikembangkan oleh Scriven yaitu Goal Free Evaluation. Goal Free Evaluation Model adalah model evaluasi yang tidak memperhatikan apa yang menjadi tujuan program sebagaimana model goal oriented evaluation. Yang harus diperhatikan justru adalah bagaimana proses pelaksanaan program, dengan jalan mengidentifikasi kejadian-kejadian yang terjadi selama pelaksanaannya, baik hal-hal yang positif maupun negatif.

Scriven mengingatkan bahwa model evaluasi yang ia kembangkan ini memudahkan bagi evaluator untuk melihat hasil dari proses evaluasi karena tujuan sudah ditetapkn di awal, sehingga apabila program berjalan lancar maka otomatis hasilnya akan baik. Namun tidak dipungkiri evaluator juga perlu mengetahui apa tujuan dari program tersebut walaupun tidak harus begitu mendalam. ${ }^{43}$ Model evaluasi semacam ini, yang nantinya dapat memberikan hasil lebih baik karena tidak tergantung kepada tujuan yang secara formalitas sudah ditetapkan, dan memberikan keleluasaan bagi evaluator memberikan nila secara objektif.

Setiap akhlak baik dapat diusahakan dengan membiasakannya dan menekuninya secara bersungguh-sungguh, serta mengamalkannya, sehingga pelakunya mencapai kedudukan yang tinggi. Begitu juga dalam evaluasi, dengan memperhatikan kegiatan yang baik, memperhatikan proses belajar

\footnotetext{
${ }^{41}$ Muhammad Abdurrahman al-Mubarakfuri, Tuhfatul Ahwadi, 46

${ }^{42}$ Muhammad Abdurrahman al-Mubarakfuri, Tuhfatul Ahwadi, 46

43 Stephen Issac dan Michael William B., Handbook in Research and Evaluation. (California, San Diego, 1983), 7
} 
peserta didik, apabila baik maka kegiatan tersebut akan diteruskan sehingga mendapatkan hasil yang maksimal. Karena itu, Rasulullah bersabda:

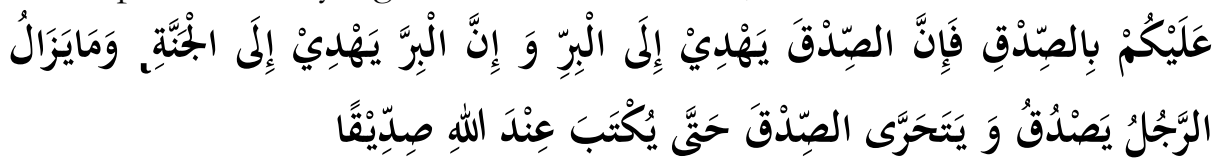

"Pegang tegub kejujuran! Kejujuran itu menunjukkan jalan kebaikan dan kebaikan itu mengantarkan ke surga. Seseorang dapat dinilai jujur bila ia (benar-benar) mengimplementasikan nilai kejujuran tersebut

Demikian pula, berbagai hal yang dusta akan menjerumuskan pelakunya ke jalan keburukan dan akhirnya dicap sebagai pendusta. Maka hal tersebut bila terjadi di dalam proses pendidikan, maka kegiatan yang dilaksanakan tidak strategis, dan kegiatan tersebut berlangsung terusmenerus tanpa ada perubahan maka hasilnyapun tidak baik. Untuk itu, perlunya model Goal Free Evaluation, untuk memperbaiki proses pendidikan dan menilai peserta didik berdasarkan proses pembelajaran. Fungsi evaluasi bebas tujuan adalah untuk mengurangi bias dan menambah objektifitas.

Evaluasi yang berorientasi pada tujuan, seorang evaluator secara subjektif persepsinya akan membatasi sesuai dengan tujuan. Padahal tujuanpada umumnya hanya formalitas dan jarang menunjukkan tujuan yang sebenarnya dari suatu proyek. Lagipula, banyak hasil program penting yang tidak sesuai dengan tujuan program. Evaluasi bebas tujuan berfokus pada hasil yang sebenarnya bukan pada hasil yang direncanakan. Dalam evaluasi bebas tujuan ini, memungkinkan evaluator untuk menambah temuan hasil atau dampak yang tidak direncanakan. Rasulullah bersabda:

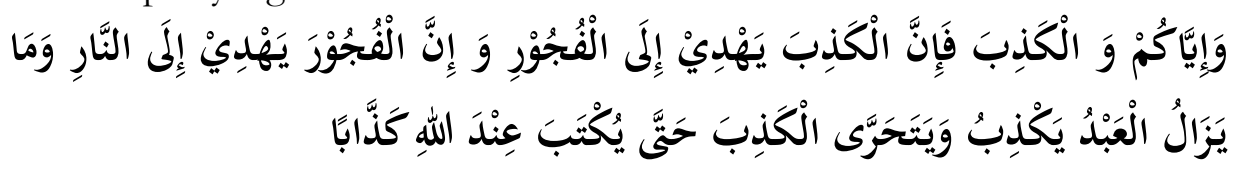

Waspadalah kalian terbadap kebohongan! Sungguh, kebohongan itu menunjukkan jalan kesesatan dan kesesatan itu mengantarkan ke neraka. Karenanya, seseorang yang seringkali berbohong serta melakukan tindak kebohongan, hingga ia dicatat di sisi Allah swt. sebagai pembohong.

\section{Simpulan}

Berdasarkan penelitian terhadap hadits at-Tirmidzi di atas, dapat disimpulkan bahwa sanad hadits tersebut bersambung yaitu muttashil marfu', 
seluruh perawi yang meriwayatkannya termasuk tsiqah, tidak terdapat syadz dan illat baik pada sanad dan matannya. Maka haditstersebut masuk dalam katergori haditsshahihdanmaqbul al-hujjah.

Sedangkan pemaknaan hadits yang diriwayatkan oleh at-Tirmidzi di atas ialahmenggambarkan tentang adanya dua hakekat perbedaan yang begitu jauh, sejauh perbedaan antara surga dan neraka. Hakekat pertama adalah mengenai al-shidq (kejujuran \& kebenaran iman), yang digambarkan Rasulullah SAW sebagai pintu gerbang kebaikan yang akan mengantarkan seseorang ke surga. Sementara hakekat yang kedua adalah kedustaan (al-kadz̧b), yang merupakan pintu gerbang keburukan yang akan mengantarkan pelakunya ke dalam neraka

Secara ekplisit makna hadis tersebut tidak memiliki kaitannya dengan evaluasi pendidikan, namun berdasarkan telaah dan analisis penulis ada implikasi makna hadis tersebut terhadap pengembangan model evaluasi pendidikan terutama yang mengembangkan evaluasi pendidikan berbasis dan belandaskan proses tanpa tujuan.Atau model evaluasi yang dikembangkan Scriven yaitu goal free evaluation.

\section{Daftar Pustaka}

Ahmad, Arifuddin. Paradigma Baru Memahami Hadits Nabi; Refleksi Pemikiran Pembaruan Prof. Dr. Mubammad Syubudi Ismail, Cet. I. Jakarta: Renaisan, 2005.

al-Azdi, Sulaiman ibn al-Asy'ats Abu Daud al-Sijistani. Sunan Abi Daud. Beirut: Dar al-Fikr, t.t.

CD Maktabah al-A'lām wa Al-Tarāijim

Departemen Agama RI. Al-qur'an dan Terjemahnya. Bandung: CV. Diponegoro, 2005.

al-Hadi, Abu Muhammad Abd al-Hadi bin Abd al-Qadir bin. Turuq Takhrij Hadits Rasulillah. Mesir: Dar al-Fikr, t.th.

Issac, Stephen dan William B, Michael, Handbook in Research and Evaluation. California: San Diego, 1983.

Ismail, M. Syuhudi. Kaidah Keshahiban Sanad Hadits. Jakarta: Bulan Bintang, 1988.

--------, Metodologi Penelitian Hadits Nabi, Cet. I. Jakarta: Bulan Bintang, 1993.

al-Maktabah al-Syamilah

al-Mazzi, Jamal al-Din Abi al-Hujjaj Yusuf. Tabdzib al-Kamal fi Asma' al-Rijal, Jilid 26. Baghdad: Muassasah al-Risalah, 1983. 
--------, Tahdzib al-Kamal fi Asma’ al-Rijal, Juz 19. Beirut Lebanon: Dar al-Fikr, 1994.

al-Mubarakfuri, Muhammad Abdurrahman. Tubfatul Abwadi. Lebanon: Dar alKotob Al-Ilmiyah, 2005.

al-Naisaburi, Muslim ibn al-Hujjaj Abu al-Husain al-Qusyairi, Shahib Muslim Juz. 4. Beirut: Dar Ihya al-Turats al-'Araby, t.t.

al-Qasthalani, Abu al-Abbas Syihabuddin Ahmad. Irsyad al-Sari li Syarh Shabih al-Bukhari, Volume XIII, Cet. I. Beirut: Dar al-Fikr, 1410 H/1990 M.

Tahhan, Mahmud. Ushul al-Takhrij wa Dirasat al-Asanid. Beirut: al-Matba'ah alArabiyyah, 1978.

Al-Tirmidzi, Abi 'Isa Muhammad ibn 'Isa ibn Saurah. Sunan Al-Tirmidzi, Juz' 3. Beirut Lebanon: Dar El-Fikr, 2003/ 1424 H.

Wensinck, A.J. al-Mu'jam al-Mufahras li Alfadz, al-Hadits al-Nabawi, Leiden: E.J. Brill, 1936 